\title{
Wieloośrodkowe badania nad walsartanem - dlaczego kolejne dane o jego wpływie na ciśnienie centralne są potrzebne?
}

\author{
prof. dr hab. n. med. Krzysztof J. Filipiak, FESC, lek. Anna E. Płatek
}

I Katedra i Klinika Kardiologii, Warszawski Uniwersytet Medyczny, Warszawa

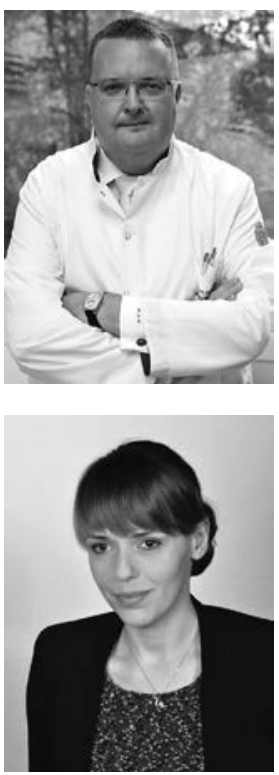

Walsartan pozostaje najczęściej stosowanym w Polsce sartanem, a zatem lekarze mają do tego właśnie antagonisty receptorów angiotensynowych największe zaufanie. Preparat złożony (single pill combination [SPC]) walsartanu z hydrochlorotiazydem jest z kolei najczęściej stosowanym SPC w Polsce. Dlatego wszelkie dane dotyczące zarówno tego właśnie sartanu, jak i jego połączenia z diuretykiem powinny być śledzone z uwagą.

„Kardiologia Polska" jest szczególnie dumna z tego, że w ostatnich latach opublikowano na jej łamach pracę oryginalną dotyczącą badania VICTORY (Virtual histology In CaroTids Observational Registry) — międzynarodowego, wieloośrodkowego programu klinicznego prowadzonego w krajach naszego regionu — w Słowenii, Czechach, Chorwacji, na Ukrainie i w Rosji [1]. W badaniu tym testowano preparaty walsartanu oraz walsartanu z hydrochlorotiazydem firmy Krka ${ }^{\circledR}$ — lidera rynku sartanowego w Polsce. To ważne, bowiem takich właśnie badań klinicznych nie wymagają w odniesieniu do leków generycznych urzędy rejestracyjne. Jeżeli jednak substytucja generyczna stanowi istotny czynnik zwiększania dostępności naszych pacjentów do nowoczesnych leków, to sami powinniśmy być przekonani do jej efektywności, skuteczności terapeutycznej, bezpieczeństwa i tolerancji. Z tego względu firmy produkujące leki generyczne nieprowadzące takich badań pozostają zdecydowanie w tyle wobec tych, które na takie międzynarodowe badania się decydują. My również apelujemy, aby obserwować krajobraz takich właśnie badań klinicznych i zdecydowanie preferować leki generyczne, nad którymi takie dodatkowe badania przeprowadzono. Jeszcze lepiej, gdy badania te zawierają elementy, których wcześniej w ten sposób nie badano nawet w odniesieniu do leku oryginalnego. Z taką właśnie sytuacją mamy do czynienia w przypadku kolejnej odsłony badania VICTORY [2].

Trwające 4 miesiące badanie kliniczne VICTORY zawierało w sobie element oceny ciśnienia centralnego za pomocą referencyjnego oprzyrządowania (SphygmoCor ${ }^{\circledR}$, Atcor Medical). Czy dane o ciśnieniu centralnym są nam w ogóle potrzebne?

Kompleksowa ocena pacjentów z nadciśnieniem tętniczym coraz częściej wykracza poza standardowe pomiary wartości obwodowego ciśnienia tętniczego wykonywane w warunkach domowych czy gabinetowych. Zwłaszcza w przypadku oceny pacjentów młodych oraz z grup podwyższonego ryzyka sercowo-naczyniowego ocena dodatkowych parametrów hipertensjologicznych pomaga w wyborze optymalnego sposobu leczenia oraz ocenie długoterminowego rokowania. W ostatnich latach szczególnie dużą uwagę przykłada się do parametrów służących ocenie sztywności tętnic, które obrazują przemiany łożyska naczyniowego będące odpowiedzią na wieloletnie zwiększone wartości ciśnienia oraz inne schorzenia powodujące remodeling układu sercowo-naczyniowego.

Innymi słowy, pomiar ciśnienia obwodowego dostarcza informacji tylko o wyrywkowej wartości ciśnienia na odległym od serca (głównej pompy mechanicznej) naczyniu; może to być wartość chwilowa, uśredniona z trzech pomiarów czy - lepiej — określana w pomiarach prowadzonych co pół godziny w ramach 24-godzinnego profilu.

Nadal jednak mierzymy ciśnienie daleko od serca — na naczyniach, które są „mało ważne” dla rokowania chorego. O wiele bardziej istotne jest bowiem zmierzenie ciśnienia np. w aorcie, od której odchodzą kluczowe naczynia do serca, mózgu czy nerek. Co więcej, pomiar ciśnienia centralnego w aorcie - naczyniu z bardzo grubą mięśniówką — dostarcza dużo więcej informacji, gdyż towarzyszące temu pomiarowi wskaźniki sztywności naczynia pozwalają odpowiedzieć na pytanie, czy już doszło do remodelingu naczynia, a więc pośrednio dają bardziej wiarygodną odpowiedź na pytanie dotyczące „istotności” nadciśnienia tętniczego. 


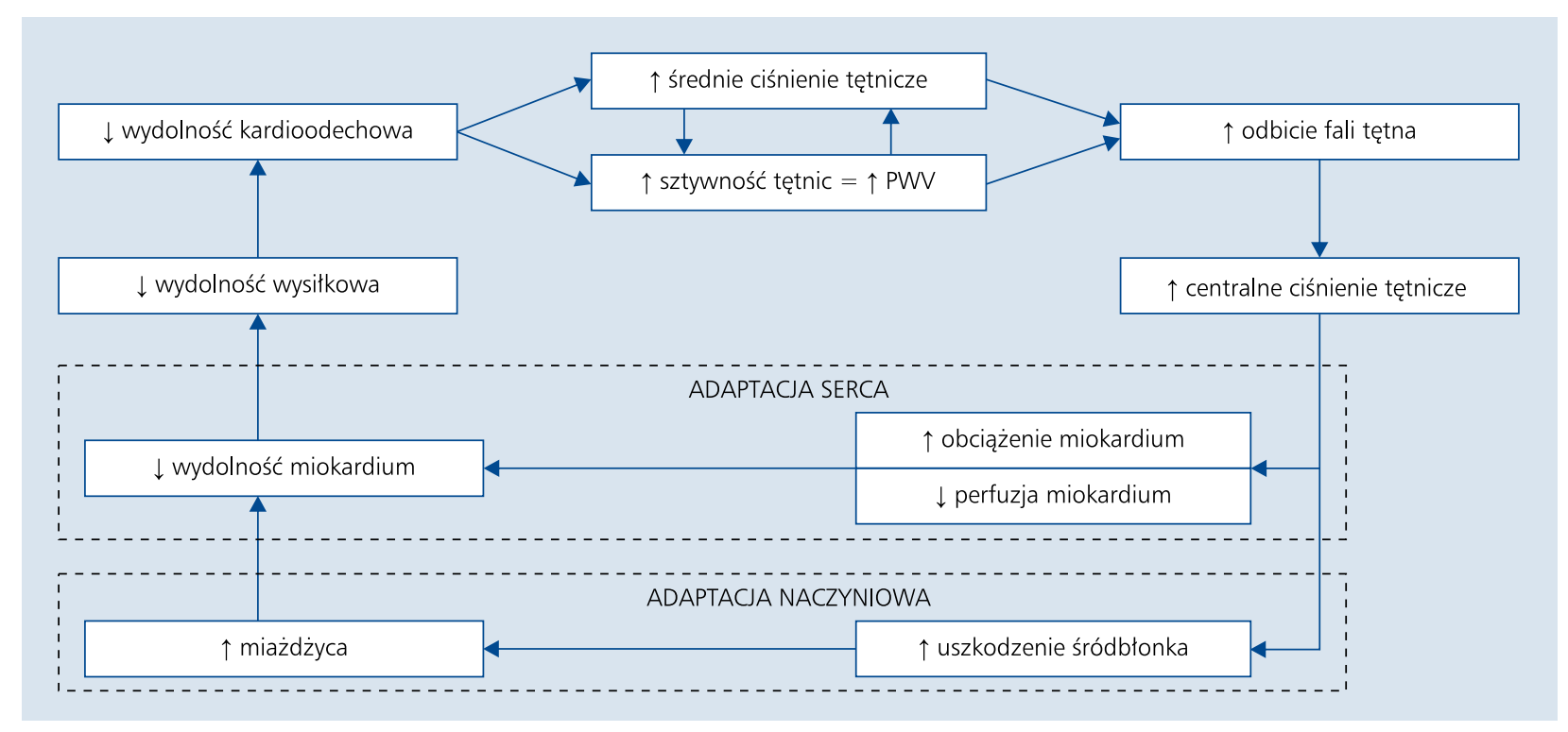

Rycina 1. Związek sztywności tętnic i zmian prędkości fali tętna (PWV) z przebudową układu sercowo-naczyniowego

Dlaczego tak się dzieje? Zwiększenie sztywności tętnic wynika ze stresu mechanicznego oddziałującego na ich ściany i sprawiającego, że zawartość podatnej na rozciąganie elastyny w ścianie naczyniowej zmniejsza się, a jej miejsce zajmują włókna kolagenowe niewykazujące już tak korzystnych rozciągliwych właściwości. Podobna sytuacja dotyczy osób starszych, u których wraz ze starzeniem się włókna elastynowe ulegają dezorganizacji i fragmentacji [3]. Jednym z najlepiej poznanych i opisanych wykładników sztywności naczyń jest prędkość fali tętna (PWV) [4, 5].

Mianem PWV określa się szybkość, z jaką fala krwi po wyrzucie z serca do aorty rozprzestrzenia się w łożysku naczyniowym. Patofizjologiczne podstawy do rozumienia prędkości rozprzestrzeniania się fali tętna w naczyniach krwionośnych wynikają z równania Moensa-Kortwega [PWV $=\sqrt{ }(\mathrm{Eh} / 2 \rho \mathrm{R})]$, w którym E oznacza moduł elastyczności Younga, $\mathrm{h}$ — grubość ściany naczyniowej, $\rho$ - gęstość krwi, a R - promień naczynia [6, 7].

To, być może, zbyt szczegółowe rozważania dla lekarza praktyka, ale warto zapamiętać, że PWV bezpośrednio wynika z elastyczności i podatności ściany naczyniowej. W warunkach prawidłowych wartości PWV są niskie, co pozwala na powrót odbitej fali tętna od obwodowych naczyń do aorty. W przypadku istnienia patologii zmienione tętnice mają mniejszą pojemność buforową, co ogranicza ich możliwość do regulowania wartości ciśnienia tętniczego. Zatem im niższe są wartości PWV, tym mniejszą sztywność wykazują tętnice pacjenta.

Pomiary PWV są stosunkowo łatwe do przeprowadzenia i charakteryzują się dużą powtarzalnością, co zwiększa ich użyteczność kliniczną. Wyróżnia się kilka sposobów ich wy- konywania. Najprostszy pomiar — segmentowy (local PWV) - odnosi się do wartości uzyskiwanych na jednym odcinku tego samego naczynia i chociaż cechuje się najmniejszym błędem pomiarowym, to w małym stopniu koreluje z rokowaniem [8, 9]. Znacznie bardziej użyteczne rokowniczo są pomiary regionalne dostarczające informacji o sumarycznej sztywności wszystkich tętnic znajdujących się między dwoma punktami pomiarowymi. Obecnie metodę referencyjną stanowią pomiary szyjno-udowego PWV. Sam pomiar wymaga możliwości wyczucia tętna na tętnicy szyjnej oraz tętnicy udowej i pośrednio mówi o sztywności aorty, naczyń znajdujących się w klatce piersiowej i jamie brzusznej, tętnic kończyn dolnych oraz tętnic szyjnych. Jest zatem miarą tego, jak obserwowana sztywność tętnic wpływa na unaczynienie ważnych dla życia organów, takich jak serce, nerki i mózg. Właśnie szyjno-udowe PWV jest przebadanym i potwierdzonym czynnikiem ryzyka wystąpienia incydentów sercowo-naczyniowych u pacjentów z nadciśnieniem tętniczym, cukrzycą, przewlekłą chorobą nerek oraz chorobą wieńcową [10, 11].

Same pomiary PWV można wykonać w sposób inwazyjny podczas angiografii, ale coraz częściej, ze względu na większą dostępność i bezpieczeństwo badania, preferuje się pomiary nieinwazyjne. Te z kolei mogą być przeprowadzone w czasie ultrasonograficznego badania naczyń, w badaniu metodą rezonansu magnetycznego albo za pomocą przeznaczonych do tego urządzeń, takich jak PulsePen ${ }^{\circledR}$, Complior $^{\circledR}$ lub SphygmoCor ${ }^{\circledR}$. Działanie tych urządzeń opiera się na pomiarach metodą tonometrii aplanacyjnej, analizy sygnału elektrokardiograficznego lub oscylometrycznej oceny fali ciśnienia tętniczego. Wykonanie badań z użyciem opisywanych urządzeń jest stosunkowo proste i nieczasochłonne, co 
pozwala liczyć na stopniowe rozpowszechnienie się oceny PWV w praktyce klinicznej [12].

Najważniejszą zaletą oceny PWV jest jego bezpośredni związek z oceną rokowania pacjentów. W licznych badaniach wykazano, że wzrost PWV wiąże się ze zwiększeniem skurczowego ciśnienia tętniczego, ciśnienia tętna, obciążenia następczego lewej komory, przerostem mięśnia lewej komory i zwiększonym zapotrzebowaniem na tlen oraz zmniejszonym ciśnieniem rozkurczowym, co skutkowało hipoperfuzją wieńcową (ryc. 1) [13-16].

Niektóre z badań epidemiologicznych ukazują związek sztywności tętnic z niekorzystnym rokowaniem w zakresie incydentów sercowo-naczyniowych, w tym tych zakończonych zgonem. Dowiedziono również istotnej zależności między podwyższonymi wartościami PWV a ryzykiem wystąpienia udaru mózgu [17-21].

European Society of Hypertension i Polskie Towarzystwo Nadciśnienia Tętniczego uznały parametr, jakim jest PWV, za korzystny do mierzenia u pacjentów z rozpoznaniem nadciśnienia tętniczego i włączyły go w zakres rozszerzonych badań wskazanych w tej grupie $[22,23]$. W wytycznych polskich i europejskich wartości PWV mierzone między tętnicą szyjną a tętnicą udową wynoszące $>10 \mathrm{~m} / \mathrm{s}$ uznano za marker subklicznego uszkodzenia narządowego spowodowanego nadciśnieniem tętniczym oraz wskaźnik uszkodzenia narządu docelowego i przydatny dodatkowy test w badaniu nadciśnienia tętniczego. Stwierdzono, że ten parametr ma większą wartość predykcyjną niż rozpowszechniona skala SCORE i każe klasyfikować pacjentów jako należących do grupy podwyższonego ryzyka sercowo-naczyniowego, co wymusza odpowiednie modyfikowanie postępowania. Obniżenie wartości PWV również uznano za jeden z korzystnych wykładników leczenia nadciśnienia tętniczego.

Badanie sztywności tętnic za pomocą PWV staje się immanentnym punktem kompleksowej oceny w zakresie wczesnego wykrywania chorób układu sercowo-naczyniowego i mózgowo-naczyniowego oraz zapobiegania im. Także stosowanie leków, które potencjalnie ograniczają wpływ na parametry PWV, w przyszłości może się stać postępowaniem rutynowym ze względu na związane z nim korzyści rokownicze.

Wróćmy zatem do komentowanego badania. W kolejnej odsłonie międzynarodowej próby klinicznej VICTORY udowodniono bezsprzecznie, że zarówno walsartan, jak i jego SPC - walsartan z hydrochlorotiazydem - skutecznie zmniejszały nie tylko ciśnienie tętnicze mierzone na tętnicy ramiennej, ale również PWV, centralne ciśnienie tętnicze skurczowe i rozkurczowe. To pośredni dowód na to, że leczenie hipotensyjne tymi właśnie preparatami niesie ze sobą dodatkowe korzyści, „odmładza tętnice”, obniża ryzyko powikłań sercowo-naczyniowych.
Konflikt interesów: Krzysztof J. Filipiak - honoraria wykładowe i konsultacje dla następujących producentów sartanów: Adamed, Berlin-Chemie, Boehringer Ingelheim, Krka, MSD, Polpharma, Sandoz, Sanofi.

\section{Piśmiennictwo}

1. Accetto R, Chazova IY, Sirenko Y, et al. The efficacy and safety of valsartan and combination of valsartan and hydrochlorothiazide in the treatment of patients with mild to moderate arterial hypertension - the VICTORY trial. Kardiol Pol. 2017; 75(1): 55-64, doi: 10.5603/KP.a2016.0135, indexed in Pubmed: 27714718.

2. Accetto R, Widimsky J, Vincelj J, et al. The efficacy and safety of valsartan and combination of valsartan and hydrochlorothiazide in the treatment of patients with mild to moderate arterial hypertension. Kardiol Pol. 2017 [Epub ahead of print], doi: 10.5603/KP.a2017.0240, indexed in Pubmed: 29192957.

3. Danpinid A, Luo J, Vappou J, et al. In vivo characterization of the aortic wall stress-strain relationship. Ultrasonics. 2010; 50(7): 654-665, doi: 20138640, indexed in Pubmed: 10.1016/j. ultras.2010.01.003.

4. Hayashi K, Yamamoto T, Takahara A, et al. Clinical assessment of arterial stiffness with cardio-ankle vascular index: theory and applications. J Hypertens. 2015; 33(9): 1742-57; discussion 1757, doi: 10.1097/H]H.0000000000000651, indexed in Pubmed: 26114836.

5. AlGhatrif M, Lakatta EG. Longitudinal perspective on the conundrum of central arterial stiffness, blood pressure, and aging. Curr Hypertens Rep. 2015; 17(2): 12, doi: 10.1007/s11906-0140523-z., indexed in Pubmed: 25687599.

6. Laurent S, Boutouyrie P, Asmar R, et al. Aortic stiffness is an independent predictor of all-cause and cardiovascular mortality in hypertensive patients. Hypertension. 2001; 37(5): 1236-1241, indexed in Pubmed: 11358934

7. Oliver JJ, Webb DJ. Noninvasive assessment of arterial stiffness and risk of atherosclerotic events. Arterioscler Thromb Vasc Biol. 2003; 23(4): 554-566, doi: 10.1161/01.ATV.0000060460.52916. D6, indexed in Pubmed: 12615661.

8. Vappou J, Luo J, Okajima K, et al. 24. Aortic pulse wave velocity measured by pulse wave imaging (PWI): a comparison with applanation tonometry. Artery Res. 2011; 5(2): 65-71, doi: 10.1016/j. artres.2011.03.002, indexed in Pubmed: 24817917.

9. Murgo JP, Westerhof N, Giolma JP, et al. Aortic input impedance in normal man: relationship to pressure wave forms. Circulation. 1980; 62(1): 105-116, indexed in Pubmed: 7379273.

10. Mancia G, Fagard R, Narkiewicz K, et al. 2013 ESH/ESC guidelines for the management of arterial hypertension: the Task Force for the Management of Arterial Hypertension of the European Society of Hypertension (ESH) and of the European Society of Cardiology (ESC). Eur Heart J. 2013; 34(28): 2159-2219, doi: 10.1093/eurheartj/eht151, indexed in Pubmed: 23771844.

11. Laurent S, Cockcroft J, Van Bortel L, et al. European Network for Non-invasive Investigation of Large Arteries. Expert consensus document on arterial stiffness: methodological issues and clinical applications. Eur Heart J. 2006; 27(21): 2588-2605, doi: 10.1093/eurheartj/ehl254, indexed in Pubmed: 17000623.

12. Pereira T, Correia C, Cardoso J. Novel methods for pulse wave velocity measurement. J Med Biol Eng. 2015; 35(5): 555-565, doi: 10.1007/s40846-015-0086-8, indexed in Pubmed: 26500469

13. Franklin SS, Larson MG, Khan SA, et al. Does the relation of blood pressure to coronary heart disease risk change with aging? The Framingham Heart Study. Circulation. 2001; 103(9): 1245-1249, indexed in Pubmed: 11238268. 
14. Salvi P, Safar ME, Labat C, et al. PARTAGE Study Investigators. Heart disease and changes in pulse wave velocity and pulse pressure amplification in the elderly over 80 years: the PARTAGE Study. J Hypertens. 2010; 28(10): 2127-2133, doi: 10.1097/HJH.0b013e32833c48de, indexed in Pubmed: 20634719

15. Segers P, Kips J, Trachet B, et al. Limitations and pitfalls of non-invasive measurement of arterial pressure wave reflections and pulse wave velocity. Artery Res. 2009; 3(2): 79-88, doi: 10.1016/j.artres.2009.02.006.

16. Nichols WW. Clinical measurement of arterial stiffness obtained from noninvasive pressure waveforms. Am J Hypertens. 2005; 18(1 Pt 2): 3S-310S, doi: 10.1016/j.amjhyper.2004.10.009, indexed in Pubmed: 15683725.

17. Boutouyrie P, Tropeano AI, Asmar R, et al. Aortic stiffness is an independent predictor of primary coronary events in hypertensive patients: a longitudinal study. Hypertension. 2002; 39(1): 10-15, indexed in Pubmed: 11799071.

18. Mattace-Raso FUS, van der Cammen TJM, Knetsch AM, et al. Arterial stiffness and risk of coronary heart disease and stroke: the Rotterdam Study. Circulation. 2006; 113(5): 657-663, doi: 10.1161/CIRCULATIONAHA.105.555235, indexed in Pubmed: 16461838.
19. Mitchell GF, Hwang SJ, Larson MG, et al. Arterial stiffness and cardiovascular events: the Framingham Heart Study. Circulation. 2010; 121(4): 505-511, doi: 10.1161/CIRCULATIONAHA.109.886655, indexed in Pubmed: 20083680.

20. Laurent $S$, Boutouyrie P, Asmar R, et al. Aortic stiffness is an independent predictor of all-cause and cardiovascular mortality in hypertensive patients. Hypertension. 2001; 37(5): 1236-1241, indexed in Pubmed: 11358934.

21. Vlachopoulos C, Aznaouridis K, Stefanadis C. Prediction of cardiovascular events and all-cause mortality with arterial stiffness: a systematic review and meta-analysis. J Am Coll Cardiol. 2010; 55(13): 1318-1327, doi: 10.1016/j.jacc.2009.10.061, indexed in Pubmed: 20338492.

22. Mancia G, Fagard R, Narkiewicz K, et al. 2013 ESH/ESC guidelines for the management of arterial hypertension: the Task Force for the Management of Arterial Hypertension of the European Society of Hypertension (ESH) and of the European Society of Cardiology (ESC). Eur Heart J. 2013; 34(28): 2159-2219, doi: 10.1093/eurheartj/eht151, indexed in Pubmed: 23771844.

23. Tykarski A, Narkiewicz K, Gaciong Z, et al. Zasady postępowania w nadciśnieniu tętniczym - 2015 rok. Wytyczne Polskiego Towarzystwa Nadciśnienia Tętniczego - wersja skrócona. Kardiol Pol. 2015; 73(8): 676-700, doi: 10.5603/kp.2015.0157. 